an Account of their Scientific, Commercial, Artistic and Historical Aspects, J. Wodiska, illustrated. Rebman, Ltd:-A new edition of Meteorology, Practical and Applied, Sir J. W. Moore. Swan Sonnenschein and Co., Ltd.-A translation of Hegel's Phenomenology of Mind, J. B. Baillie; Thought and Things: a Study of the Development and Meaning of Thought, or Genetic Logic, Prof. J. M. Baldwin, 3 vols., vol. iii., Real Logic; The History of Philosophy, based on the work of Dr. J. E. Erdniann, translated and edited by Prof. W. S. Hough; Physiological Psychology, Prof. W. Wundt, a translation of the fifth and wholly re-written German edition by Prof. E. B. Titchener, in 3 vols., vol. ii., illustrated. The University Tutorial Press, Ltd.-Hygiene for Training Colleges, Dr. R. A. Lyster. T. Fisher Unwin.--Psychotherapy, Dr. H. Münsterberg. Williams and Norgate.Science, Matter and Immortality, R. C. Macfie.

\section{THE BRITISH ASSOCIATION AT WINNIPEG. SECTION L.}

EDUCATIONAL SCIENCE.

Opening Address by the Rev. H. B. Gray, D.D., Warden of Bradfield College, Berkshire, President OF THE SECTION.

The Educational Factors of Imperialism.

AMONG all civilised races and in all epochs of the world's history there has existed an inveterate belief that the particular age in which men live is fundamentally distinct from those that have preceded it.

Even in the most stagnant periods the illusion has prevailed that the present day is a period of flux and movement more or less organic, and as such either to be welcomed or to be deplored.

Notoriously dificult, however, as it is to gauge the temper of an age while we live in its midst, yet the phenomena in England at the beginning of the twentieth century seem so unmistakably marked that even a superficial thinker can hardly fail to recognise the spheres in which the symptoms of change and unrest are clearly operating. They are surely in these two-the sphere of education and the sphere of Imperial sentiment.

It may not appear inapposite, therefore, if, meeting as we do in this city of phenomenal growth and infinite enterprise, our thoughts were to be directed in my inaugural address on the science of education towards discovering what may be either called the Imperial factors in education, or conversely, and perhaps more properly, the educational factors in Imperialism.

It may be perhaps safely said in this great Dominion what might possibly be disputed in the academic groves of our ancient English universities, that there was no width of educational outlook within our own little. island until the last thirty years of the nineteenth century.

The only strongholds of learning which presumed to give the lead to English secondary education were to be found on the banks of the Isis and the Cam. In these antique, I hesitate to say antiquated, fastnesses, the "grand old fortifying classical curriculum" was, until lately, regarded as the main, if not the only, highroad to educational salvation. They preserved, indeed they preserve to this day, almost the same entrance bars against admission to their thresholds as existed in pre-Reformation days. And, conformably with the pursuit of these ideal studies, the vast mass of their emoluments were, and still are, appropriated to the pursuit of the ancient models of education.

The result of this monopoly on the lower rungs of the educational ladder has been obvious, and, to a scientific thinker, lamentable. The curricula of the public secondary schools have been narrowed, or rather have never been widened coincidently with the development of new spheres of knowledge and enterprise. The students in those institutions have been dominated from above, for just as "where the carcase is, there will the eagles be gathered together," so where the emoluments have been, thither do the cleverest students concentrate their intellectual forces.

The ambition of the ablest boys has been inevitably and exclusively concentrated on a single line of study, and NO. 2084 , VOL. $8 \mathrm{I}]$ (as often happens in the minds of the young) other no less humane but entirely unendowed departments of human knowledge have been laughed down and despised. Opprobrious epithets, even, have been bestowed on the study of the natural sciences, while those modern linguistic achievements which opened the door to the treasures of French and German literature are still nothing accounted of in the great schools of England.

But (more marvellous than all) even the scientific acquisition of and familiarity with the literature of the mother tongue have been entirely neglected, because no room could be found for it in a time-table, three-quarters of which is confined for the great mass of boy students in the historic schools of England (whatever their tastes and capabilities) to the exclusive study of the grammar, literature, and composition in the languages of ancient Greece and Rome. And the particular methods pursued in this confined curriculum have rendered the course more straitened still. The acquisition of the literatures of the two dead languages and of the great thoughts buried with them has given place to a meticulous study of the subtleties of scholarship, and students are taught to wanton in the abnormalities of the words and phrases in which those literatures were enshrined, so that in the mind of the classical scholar the form has become, or at any rate became until quite lately, more important than the substance.

Nor is this all. Those who cannot find any stomach for such drenching doses of mediæval learning are actually driven away prematurely as lost souls from those mossgrown seats of learning, which we acclaim as the great public schools of England; and, with moral characters only half-fledged, have either been condemned to the limbo of private tuition or sent as "submerged tenths" to find, or lose, their fortunes in the great dependencies and dominions of the Empire like that in which I am speaking to-day. There has been no serious attempt made until the twentieth century by the leaders of our best-known places of secondary education to discover the bents and aptitudes of the boys committed to their charge and to give them any educational chance if they have not possessed that particular kind of perception which could find its way through the subtleties of a Euripides or a Horace. Boys have been entirely denied the opportunity of showing their mental powers in any other sphere of learning. How many unsung Hampdens or mute, inglorious Miltons of mechanical genius have been lost to the world by the non-elastic systems prevailing (even now) in our best-known educational institutions, is a tremendous responsibility for conscientious trainers of the young to contemplate and atone for.

In how many, or rather how few, places of learning in England, at the present time, can the establishment of scientifically equipped carpentering and engineering shops be found in which a young mind which finds it impossible to digest the crude morsels of Latin and Greek grammar can find resource and development? In how few schools has the connection between mind and hand and eye been scientifically trained? Such establishments, even in the first decade of the twenticth century, can be counted on the fingers of one hand.

And yet, in spite of it all, the surprising fact remains - f fact which speaks volumes for the innate vigour and originality of the English race-that, out of the stream of young men which flows out annually from our public schools $^{1}$ and colleges, so many accommodate themselves as happily as they do to the startlingly new conditions which confront them when they pass over the seas and swell the tide of population in great centres of industry and enterprise such as that in which we stand to-day. Their educational vision, however, has had such a narrow and limited horizon that no wonder a large proportion are not very adaptable to the practical life of the prairie and the forest, or even of the counting-house and the nffice stool. Am I, or am I not, correct in hazarding the conjecture that many specimens of this really fine Finglish breed from the old country come to you here in this Dominion without an elementary knowledge of the

$1 \mathrm{It}_{\mathrm{t}}$ should be noted in the forefront of this addrees that the expression "puhlic srhools" is used throughout in its English (not in its. more proper and American) sense-i.e., as the educational centres of the upper classes. 
laws of the world in which they live, full of antiquated prejudice and tradition, derived principally from the straitened area of their island-home experience, so that not seldom they put their hand to the plough (either literally or metaphorically) and look back, becoming wastrels instead of forceful citizens in this ever-widening Empire? "No English need apply" has been, if I mistake not, written as a memorandum inside the breast of more than one leader of industry in this great continent, and small wonder is it when the cramping character of the ultra-mediaval training which our young men have received at some of our historical public secondary schools in England is taken into account.

What remedy (you may ask) have I to propose? My answer is this: I want to force upon the attention of English educationists certain Imperial factors which should occupy an indispensable place in the educational curricula of the great schools in the Mother Country.

I would give a prominent place to the scientific teaching of geography, and particularly to historical geography, with special reference, of course, to the origin, growth, and progress of the British Empire. Such a volume as the "Sketch of a Historical Geography," by Keith Johnston, should be placed in the hands of every boy, and be known by him from cover to cover. It can hardly be realised that in many of our great classical schools to this day not more than one, or at most two, hours a week are devoted to this subject, and that it is often not taught at all beyond the middle classes in a school.

Again, I would enforce an elementary knowledge science on every boy who passes through the stage of secondary education.

I am aware that many hard things have been said about the teaching of science in secondary education. A learned professor, who is the president of another section of the association, has passed his opinion that, as taught in our schools, it has proved of little practical or educational value. But because the methods employed have been halting, insufficient, and unscientific, it by no means follows that it should be left out of the category of school subjects. On the contrary, it appears astounding that two-thirds of the public-school boys of England should grow to man's estate without even an elementary knowledge of the laws of the world in which they live.

I.ord Avebury, in his presidential address at the International Moral Education meeting held in London last autumn, told his audience an amusing story of how, walking back one beautiful summer night from the House of Commons arm-in-arm with a leading luminary on the Fovernment benches, his companion, who had been at Eton and Oxford, gazing at the great luminary in the heavens, pensively observed: "I wonder, my dear Iubbock. whether we shall ever know why the moon changes her shape once a wrek at least?"

To one who aspires to seek his fortune in the wide and half-unexplored continents of Greater Britain the value of the knowledge of chemistry, gcology, botany, and arboriculture can hardly be overestimated. And yet many present here could bear critical witness to the fact that a large proportion of young men go out to the Vorth-lWest totally unequinped, after their public-school training, with even the most elementary knowledge of those denartments of science to which I have alluded. No wonder, again, "No English need apply." Every routh we export to vou ought educationally to bear this label, on his back: " Every secd tested before being sent

But above and beyond all there should be brought into the foreground a co-ordinated studv of English language and Fnglish literature. Nothing impressed me more in my visit to the United States in 1903 as one of the Mosely Commission, than to obscrve how greatly the cultivated classes in the Federation outstrinned our island-bred people in the facility and power with which thicy manipulated the English tongue. Awkwardness. poverty of expression, and stammering utterance mark many Englishmen of high academic distinction. But the American who, on account of the incessant tide of immigration, has to assimilate the congeries of all thr nations of the earth in the shortest possible soace of time, has so co-ordinated the study of his ancestral tongue No. 2084 , vor. $8 \mathrm{r}$ ? in the schools of his country, that the pupil emerges completely equipped for the use of persuasive and oratorical languagre wherein to express his thoughts and wherewith to gain his ends.

In connection with this, may I add that it was indeed a happy augury that, at the eve of the meeting of the British Association in this great Dominion, there should have been a gathering of delegates of the Imperial Press in the centre of our small island home? "Little they know of England who only England know." The phenomenal, or rather abysmal, ignorance of the geography and of the vastness of the productive power of the british Empire which exists among the upper and middle classes in England would be ludicrous if it were not so deplorable. The loyalty and devotion of the Colonies, right unto the utmost corners of the earth, admit of no dispute. It is observable on every hand and in every national crisis. The doubt is of the loyalty of the centre of the Empire towards its extremities, through the crass ignorance which exists as to the geographical and political meaning of that Empire. I would annihilate that ignorance, as aforesaid, by putting political, historical, and physical geography in the forefront of our educational system; by lectures from your able men in Canada, or Australia, and South Africa, vivified by lantern-slides, and encouraged and endowed by the Mother Country. I would bring all visible means of presentment to bear on the education of childhood, boyhood, and youth in the Motherland.

Let me touch on one further educational factor of Imperialism. The sentiment of patriotism, unlike that of charity, is not equally capable of indefinite intension and extension. The peculiar system of education which finds vogue in England in most of our greatest institutionsthe institutions from which are drawn the future leaders of the nation-is, as everyone knows, the barrack system, otherwise called the boarding system. It is not the time or place here to cnlarge on the obvious advantages of that systen, its unique characteristics, its power of moulding character and developing enterprise. But it has its cramping and confining side-it has a tendency to localise patriotism, to narrow a young man's mental horizon, and to ignore whatever lies outside its immediate survey. Hence, the abnormal and gladiatorial devotion to games and comparatively selfish amusements, which absorb, and, in my opinion, not seldom paralyse and stifle wider, more gencrous, more enlightened-in fine, more Imperial instincts. However much in the field of sports the individual youth may subordinate his own self-regarding impulses to the welfare of the tiny community for which he is exercising his energies, his horizon is not wide enough to bid him rise to a sentiment of self-sacrifice and self-abandonment on behalf of a greater and more abstract ideal-love of Fatherland and loyalty to Empire.

But it is a welcome thing to be able to point to a larger sentiment lately awakened in this direction. There is no doubt that the patriotic spirit in our schools and colleges has, from whatever cause, received a great impetus in the last two years, and that the general principles of an intelligent defence of our shores from foreign aggression have bcen taught and construed into terms of scientific trainings and co-operative action with a rapidity equally surprising and welcome to those who, a few ycars aso, lonked with something more than apprehension on the supineness of the youth of England in all patriotic regards.

"The flannelled fool and muddied naf,"

though they have not yet received their quietus, have been less rampant lately in our educational institutions, and something like an Impcrial instinct, born of increasing knowledge both of the glory and dangers of our vast Empire, has, at least in the more cultured classes, taken the place of apathy, disregard, and ignorance. In hours formerly lavished to an abnormal extent on trivial amusements, and even in hours hitherto devoted to more academically intellectual training, we find young men in our schools and colleges now with arms in their hands, shooting, signalling, scouting, and studying scientifically the art of defensive warfare. This, at least, is "a beam in darkness, of which we pray that it may grow."

Time and your patience will not allow me to touch on more than the fringe of the great educational problems 
which have to be solved before we can approach in English education to what I venture to call the ideal of Imperial responsibility.

In criticising the old mediæval system of education which prevailed in England until comparatively recent years, and which still has far too great a hold on the more venerable and important institutions of our island home, I would not have you suppose that I am an advocate of a complete, or even approximately complete, basis of utilitarian education. It is an easy charge for those who desire stare super antiquas vias to throw in one's teeth. I have little hesitation in expressing my belief that the time has come (and I speak as one whose training was that of a classical scholar, for I was brought up in the straitest sect of academical Pharisees)-I say I have no hesitation in expressing my belief that the time has come, not only that the study of the two ancient languages should be reduced to one for all except scholastic specialists, but also that both should yield pride of place in our educational system to the claims of English, modern languages, mathematics, natural science, and, not least, manual training, so that our young men should be fitly equipped to put their hand to any work which may confront them amid all the complex problems and critical situations to be found within the world-wide boundaries of the British Empire.

Germany, France, and the United States have been beforehand with us in the working out of such a reformed system of education. I am by no means one of those who believe that we should be wise in copying the methods in their entirety of any of these three peoples in their educational methods. Undoubtedly in all three there has been a more organised connection between the actual teaching given in their respective schools and the industrial, social, and political needs of the respective peoples. But no one nation is exactly like another nation in its temper and genius, and I should be sorry to advocate, for instance, the highly organised system of State education in Germany, under which it could be predicted to a certainty that boys and girls in every secondary or primary school on any given Friday morning should be studying (say) the geographical importance of Natal or the outlines of the coast of Lincolnshire. There must be many educational differences, because the idiosyncrasies of each nation differ from those of another, and I do not think we need ever fear that our intrinsic individuality will be crushed into any Teutonic cast-iron mould or ground down beneath the heel of some bureaucratic educational despotism. But that we ought to change our ways still more than we have, and adopt saner educational models, many searchings of heart through a long educational career have gradually, but overwhelmingly, convinced me. If we are apt to think, speak, and act Imperially, our education must take form from a strong Imperial sentiment, and must aim at instilling Imperial instincts in the young lives which that education is meant to control and develop.

I have spoken hitherto of this subject mainly from the point of view of secondary education, with which I am the most conversant: not only for that reason, however. but because most of those who are destined to proceed to the distant outlying parts of the British Empire, and, when there, to take prominent parts in the development of that Empire, obtain their educational equipment from the secondary schools of England. It is, therefore, on curricula offered or desiderated in them that I have exclusively dwelt. But I do not blink the fact that the proper educational organisation of our elementary schools on the one hand, and of our universities on the other, exercises a large influence on the solution of Imperial problems.

On elementary education, however, I do not propose to touch in this address, mainly because I look forward to experts in primary schools directing the thoughts of this association more directly to them. But I will touch with great brevity on the subject of university education.

Whether Oxford and Cambridge-particularly Oxfordwill ever so reform themselves as to contribute largely to such solution remains to be seen. Personally, I look with far greater confidence to the more recently organised universities-those of London, Leeds, Sheffield, Man- chester, and the like-to equip men educationally with those moral, physical, and intellectual qualities which are most in requisition in our great dependencies and commonwealths.

Such institutions, from their newness, their eagerness, their freedom from antiquated prejudices and vested interests, are more likely to be counted upon for many years to come to send forth a stream of young men who have learned in the school of hardness to face the difficulties and to adapt themselves to the austere conditions which are inseparable from life in unworked regions and half-discovered continents. And it is at once a hopeful and inspiring thought that the great Dominion of Canada will welcome such to herself as sufficient and efficient citizens of her all but boundless territories, that she will recognise in them "bone of her bone and flesh of her flesh," physically, mentally, and morally capable, in company with those of her own sons who have long settled in the land, of extending the borders of the Empire by enlarging its resources, and of lifting, securing, and consolidating thereby the destinies of the Anglo-Saxon race.

There is still one more educational factor on which $I$ would ask attention before I close this address. It is this-the necessity of a closer touch educationally (in the sense of " academically") between the secondary schools and colleges of the Mother Country and similar institutions in the great Dominion and commonwealths which own her parentage. How this can be effected without great modification of our existing English system it is hard to see. But one point is quite clear. We must give up that part of our system which insists on choking the passage of the student from point to point in his educato the privileges of further education, if such examination on entrance and throughout his academical course. It would be of incalculable advantage to the Empire at large if an extension of educational intercommunion, such as was inaugurated by the noble benefactions of the late Cecil Rhodes, could be secured throughout the Empire. Undoubtedly examination would be the surest test for determining the question of the admission of a student to the privileges of further education if such examination could be conducted within a limited geographical area. But it is quite an impossible system if adopted as between the outlying parts of a great empire. The United States of America have taught us a better way. For instance, in the State of Minnesota, the university has legislated that if and when the principal of a high school of recognised position certifies that a student has successfully pursued for a specified length of time those studies in that high school that would entitle him to admission to the university, he should be admitted thereto without further delay or hindrance. What a paralysing curse the Charybdis of examination has been to all true learning only those who have suffered from it for thirty years can bear adequate testimony. It would be one of the most fertilising sources from which to secure good and progressive citizens if, instead of admitting within her borders all or any who came of their own spontaneity or from compulsion (leaving their country, perchance, for their country's good), the Government authorities in the Dominion could get into closer touch with the educational authorities of the Mother Country, who would act as guarantee that the material sent out by the Mother Country should be of an approved and first-rate quality. This might be worked on the American " accredited school" system, under which the authorities of the schoof sending the pupil should feel the maximum of responsibility in recommending his admission to the academical, or the technical, or the industrial organisations existing in the Dominion.

Since penning the first sentences of the above paragraph last June my eye has been caught by a notice which appeared in the columns of the Times on the 28 th day of that month while I was engaged in the very act of correcting the proofs of this address; but I prefer to leave the paragraph written as it stands, as the notice in question is an eloquent commentary on my suggestion of educational intercommunion.

I may, perhaps, be allowed to read the extract from the Times verbatim, though it may be familiar to some *O. 2084, VOL. 8I] 
at least among my audience. It is headed "International Interchange of Students-a New Movement."

"We have received," says the Times, "the following interesting particulars of a new educational movement to provide for the interchange of University students among the English-speaking peoples.

"The object is to provide opportunities for as many as possible of the educated youth of the United Kingdom, Canada, and the United States (who, it is reasonable to suppose, will become leaders in thought, action, civic and national government in the future) to obtain some real insight into the life, customs, and progress of other nations at a time when their own opinions are forming, with a minimum of inconvenience to their academic work and the least possible expense, with a view to broadening their conceptions and rendering them of greater economic and social value, such knowledge being, it is believed, essential for effectual leadership.

"The additional objects of the movement are to increase the value and efficiency of, as well as to extend, present University training by the provision of certain Travelling Scholarships for practical observation in other countries under suitable guidance. These scholarships will enable those students to benefit who might otherwise be unable to do so through financial restrictions. It also enables the administration to exercise greater power of direction in the form the travel is to take. In addition to academic qualifications, the selected candidate should be what is popularly known as an 'all-round' man; the selection to be along the lines of the Rhodes Scholarships.

"The further objects are to extend the influence of such education indirectly among the men who are not selected as scholars (through intercourse with those who have travelled) by systematic arrangements of the periods' eligibility while they are still undergraduates.

"To promote interest in imperial, international, and domestic relations, civic and social problems, and to foster a mutual sympathy and understanding imperially and internationally among students.

"To afford technical and industrial students facilities to examine into questions of particular interest to them in manufactures, \&c., by observation in other countries and by providing them with introductions to leaders in industrial activity.

"To promote interest in travel as an educational factor among the authorities of Universities, with a view to the possibility of some kind of such training being included in the regular curricula.

"To promote interest in other Universities, their aims and student life, the compulsory physical training, and methods of working their ways through college, for example, being valuable points for investigation.

"To promote international interchange for academic work among English-speaking Universities; and, in the case of the British Empire, to afford facilities for students of one division to gain, under favourable circumstances, information relative to the needs, development, and potentialities of other divisions; and to promote an academic interchange of students among the Universities of the Empire.

"As already indicated, there is a widespread interest in the movements so far as the United Kingdom is concerned; while in Canada and the United States there is also a widespread recognition of the value of the scheme; and although committees have not been actually organised there as in this country, a very large body of the most prominent educationists are strongly in favour of the plan, and have promised their. co-operation if the scheme is financed.

"It is proposed to establish two students" travelling bureaux, one in New York and one in London; an American secretary (resident in New York) and a British secretary (resident in London), both of whom shall be college men appointed to afford every facility to any graduate or undergraduate of any University who wishes to visit the United States, Canada, or the United Kingdom for the purpose of obtaining an insight into the student, national, and industrial life of those countries. The bureaux will undertake the work of providing information relating to United States. Canadian, British, and other
English-speaking Universities for the use of students, undergraduates, and others. They will also provide information relating to educational tours of any description in English-speaking countries, and the arrangement of tours suitable to the needs of the inquirer with a view to his obtaining the greatest facilities for education with a minimum of expense. Furthermore it will be their duty to provide information as to the best places for the study of educational, governmental, industrial, and social problems in the United States, Canada, the United Kingdom, and other parts of the Empire, as well as to provide introductions to leaders in the above-named spheres of activity, besides undertaking the organisation and conduct of special tours for educational purposes, if necessary.

"It is proposed to provide 28 travelling scholarships, 14 of these being available for Universities in the United Kingdom, Io for Universities in America, and four for Universities in Canada. The arrangements will be controlled by general committees, one for the United Kingdom and one for Canada and the United States, unless it is found necessary to inaugurate a separate committee for each of the latter."

You will observe, then, that a scheme which I had ventured to suggest as being "of incalculable advantage to the Empire " had, before I wrote the words quoted, been advocated entirely without my knowledge by a body of influential educational leaders in England, whose names were appended to the notice which I have read; and I need only add that it is quite certain that I am interpreting the sentiments of all here assembled in wishing Godspeed to the development of the scheme, which seems likely to prove, if carried into effect, a great, if not the greatest, educational factor of Imperialism.

But it may be objected here, Is not your own horizon circumscribed? Why should educational ideals be limited, even by so extended a conception as Imperialism? Should not the ultimate aim of all education be, not the federation of one race only, but the federation of the world at large - the brotherhood of man?

I am not concerned to deny that such a lofty conception is the true end of all physical, moral, and mental training.

But if the master mind of a Milton was; content to define true education to be "that which fits a man to perform justly, skilfully and magnanimously all the offices, both public and private, of peace and war," it may well suffice us if we extend our (at present) too narrow conceptions (the aim of which seems to be the cultivation of a mere island patriotism) to a sphere which has for its end the imperialistic sentiment of a whole race.

It may, indeed, be well doubted whether a race-sentiment is not an ultimate factor beyond which it is impossible in an imperfect world to go. Universal philanthropy in its most catholic sense is a sentiment which the limited conditions of the earth's surface seem to render impossible. So long as men's ambitions are an unlimited quantity, and so long as the habitable globe remains, as it ever must remain, a limited quantity, so long will the populations of the world be continually liable to shifting movements and frequent dislocations. Practical educationists, then, must inevitably confine the scientific consideration of aims and methods in education to the development of the highest interests of their race rather than of mankind at large.

And that being so, the last point on which I would insist in dealing with the educational factors of Imperialism is to emphasise the importance of what the educationists of the United States call "civics", as the binding power which should fasten together all the separate educational faggots in any Imperial scheme of education-the duty of personal service to the State, the positive obligation which makes us all members incorporate in one Imperial system. In our love of individual freedom, in our jealousy of interference with our individual liberty of action, in our insular disregard and depreciation of intellectual forces working in our sister communities beyond the seas, we have lost sight of this civic responsibility which has ever lain on our shoulders and from which we can never dissociate ourselves, so long as our Empire remains as part of our ancestral heritage.

NO. 2084, VOL. $8 \mathrm{r}]$ 
It is this positive duty towards each other and our race beyond the seas which those who live in our island home have been slow in realising, and it has been a real blot on our educational systen that such ideas as Imperial responsibility and Imperial necessitics have not been inculcated in the young people in our schools and colleges. As an illustration, I may observe that it has been even debated and doubted in some responsible quarters in England whether the L'nion Jack should wave over our educational institutions on the days of national festivity and national observance.

To sum up. By these and other kindred means I would urge a closer educational touch between the Mother Country and the Fmpire at large.

Long ago a great Minister was able to say: "Our hold of the Colonies is in the close affection which grows from common names, from kindred blood, and from similar privileges. These are ties which, though light as air, are strong as links of iron."

But times have changed. To-day we are confronted with the problems of a vast and complicated Empiregreat commonwealths, great dominions, sundered from each other by long seas and half a world, and hovever closely science has geographically brought them together, we cannot in soul and sympathy, nor ultimatelv in destinv. remain attached, affiliated as mother and children should be, unless we grapple to each other and understand each other in the greatest of all interests-the educational training which we give to our children in the one part of our Empire to make them suitable citizens in another.

In suggesting reforms and modifications in which this educational unity may best be expressed, forgive me if I have but touched, and touched inadequately, on the fringe of a great subject. the transcendent importance of which it requires no elaboration of mine to imnress on the earnest attention of the people of this great Dominion - which great Dominion mav I be allowed to salute, withnut flattery or favour, as the most favoured by natural beauty and by virgin wealth of all the children of nur rommon Motherland? May $T$ salute her in terms which formed the old toast with which the two greatest of our English public schools, Winchester and Eton, pledged each nther when we met in our annual cricket contest: Mater pulchra, filia tulchrior!

GEOLOGY AT THE BRITISH ASSOCIATION.

$I^{F}$ the number of geologists from the British Isles who attended the meeting of Section $C$ was somewhat limited, the number from the American continent was considerable, and it was greatly to them, and especially to those from Canada, that the markedly successful character of the sectional meetings was due. The Canadian geologists not only contributed a particularly interesting series of papers, but also arranged two excursions, which were largely attended.

The papers read before the section maty be classified in four groups.

\section{(1) Stratigraphical Geology.}

Mr. J. B. Tyrrell's account of the geology of Western Canada, which followed the president's address, afforded an excellent introduction to the succeeding series of papers on local geology. Pre-Cambrian geology naturally occupied a good deal of the attention of the section, which had the advantage of hearing papers by Prof. A. P. Coleman on the bearing of pre-Cambrian geology on uniformitarianism, and by Prof. W. G. Miller on the pre-Cambrian rocks of Canada. Prof. Coleman described the somewhat complicated subdivision which Canadian geologists recognise in the pre-Cambrian rocks, and pointed out the varied nature of their origin, including as they do quartzites, sandstones sometimes passing into arkose, carbonaceous shale, limestone, igneous rocks both volcanic and intrusive, and metamorphic rocks in great variety. The most interesting point about Prof. Coleman's paper was the evidence he brought forward for the existence of glacial conditions in pre-Cambrian (Huronian) times, and the bearing of this on uniformitarianism. He exhibited stones which he had extracted from the pre-Cambrian conglomerate of the Cobalt district, the upper surface of which was scratched by the Pleistocene glaciation, while the lower (embedded) surface NO. 2084 , VOL. 8I] after extraction, also showed stria which it was difficult to distinguish from those produced by the Pleistocene ice. In the subsequent discussion Drs. Fairchild, Strahan, Warren I"pham, and Dwerrvhouse expressed the opinion that Prof. Coleman had established his contention.

Prof. Miller's papter was chiefly directed to bringing into prominence the almost limitless mining possibilities of the Canadian pre-Cambrian rocks. He pointed out that although they have as yet been very imperfectly explored, they are already, in the Cobalt and Sudbury districts, the chief, or among the chief, world's source of nickel, cobalt, silver, and arsenic, while in the Michigan district their yield of copper and iron is one of the most importan in the world. The same may be said with regard to the micat mines of (Ontario.

The stratigraphy of the Palacozoic rocks of the British Istes was represented by the reports of several of the association's committees, including the followins:-(I) $\mathrm{Mr}$. E. S. Cobbold, un the Cambrian rocks of Comley, Shropshire; (2) I'rof. S. H. Reynolds, on the igneous and associated rocks of the Glensaul district, Co. Galway; and (3) I)r. A. Vaughan, on the faunal succession of the Lower Carboniferous (Avonian) of the British Isles. The latter report included an important series of tables embodying Dr. Vaughan's latest views on the subdivision of the I.ower Carboniferous rocks, and the correlation of the sequence in various parts of the British Isles. With the virw of helping to bring Dr. Vaughan's work to the notice of Canadian geologists, Prof. S. H. Reynolds exhibited a series of lantern-slides of the two principal sections of the Fristol district, those of thr Avon and of Burrington. It also contributed a paner on the lithology of the Burrington section. Another stratisraphical paper havines reference to the Carboniferous rocks of the south-west of Fingland was that by $\mathrm{Mr}$. H. Bolton, on new faunal horizons in the Bristol coalfeld, in which further evidence was brought forward of the occurrence of marine episodes in the Coalmeasures of this part of the country. The only remaining stratigraphical paper was one by I)r. I). Woolacott, on the classification of the Permian rocks of the north-east of England.

(2) Glacial Geology.

Glacial geology naturally had much attention paid to it by the section when meeting in Canada, and the members were to be consratulated on hearing from Dr. Warren Ipham an account of the glacial Iake Agassiz, in connection with which his name is so well known. $\Lambda$ t its maximum extent, accordings to I)r. Upham, it covered an area of about 110,000 square miles, exceeding the combined areas of the five great lakes tributary to the St. Lawrence. I.ake IVinnipeg forms its reduced representative at the present day. Dr. Upham's paper was followed by an interesting discussion, in which many leading Canadian and American geologists tonk part. Members of the section had, further, the opportunity of seeings some of the glacial and other deposits of I.ake Agassiz on excursions which were made to Stony Mountain and Bird's Hill.

Prof. A. $P$. Coleman, in a paper on the extent of the ice sheets in the fireat Plains, pointed out that while boulders from the Archean region to the east are spread over the great plains as far west as Calgary, further to the west in older drift, derived from the Rocky Mountain region, is met with, this sometimes passing below the eastern drift. In places boulders from the eastern drift are found stranded 5ono feet un on the sides of the Rocks Mountains. These Prof. Coleman believes were stranded from ice-dammed lakes at a time when the Rocky Mountain resion stood at a lower level than it does at present.

Glacial geology was further represented by a paper by Dr. A. Strahan, on the Elacial geology of South Wales; bv a lantern lecture by Dr. A. R. Dwerryhouse, on the glacial geology of Britain, as illustrative of the work of the enminittere on erratic: hlocks, and by the report of the committee for the investigation of the fossiliferous drift at Kirmington, Lincolnshire, and elsewhere.

(3) Economic Gcology.

This subject, as might have been expected, was well to the fore, a series of most interesting papers on the ore deposits of canada beings given by Canadian geologists. Prof. WV. G Miller dealing with the gold, silver, and iron 